\title{
エジェクタ形ノズルを有する 空気マイクロメータの研究
}

（静特性について）

\author{
鈴 木 善 雄* \\ Studies on a Pneumatic Micrometer with an Ejector Type Nozzle \\ (on Static Characteristics) \\ Yoshio Suzuki*
}

This paper describes the static characteristics of a pneumatic micrometer with an ejector type nozzle. This type nozzle is a unit which consists of the nozzle, the output port and the supply port set up at a very near position from the nozzzle.

From experimental results, it was found regarding static output characteristics that the ouput flow rates and the output pressures became negative when the nozzle-flapper gaps became large, and regarding transfer characteristics, that the linearity was better than on that of the thickness comparator type pneumatic micrometer with a single nozzle.

A theoretical analysis was presented for the low supply pressure case, assuming that the pressure at the jet impinging part rose because of the momentum change of the jet impinging on the nozzle and the flapper. Then it was evident that a parameter $\lambda_{0}$, which related to the pressure at the jet impinging part, explained the character of the ejector type nozzle and equaled approximately 0.36 when the design was done well.

The theoretical results showed a good agreement with the experimental results. The author gave a critérion for the design of an ejector type nozzle. This nozzle will be profitable as a pneumatic sensor, particulary when we need a large output flow rate for low loads, and it has wide applicability.

\section{1. 緒言}

純流体比例素子の動特性解析のための空気式正弦波 信号発生器として，1噴口厚み計形空気マイクロメー

†第 11 回計測自動制御学会学術講演会で発表（昭 $47 \cdot 8$ )

* 福井大学工学部 福井市文京 3-9-1

* Faculty of Engineering, Fukui University, Fukui (Received May 2, 1973)
タを利用するあのがある．乙の場合，出力信号の線形 性および周波数特性が優れていること, および出力流 量変換特性の大きいととが必要とされる. 線形性を得 るためには，山本 ${ }^{1)} は$ ばローおよびばねによるフィー ドバック機構を用いて行なっているが，乙の形式のノ ズル系ではノズル背圧室の容積が小さくできないの で, 数 $\mathrm{Hz}$ 以上の高周波の発振がむずかしいため, 純 流体素子の動特性試験には不利である

そこで，背圧室の容積を小さくするために，供給 口，ノズルおよび出力口を一体化し，さらに供給口を ノズルに非常に近づけたノズル（以後エジェクタ形）

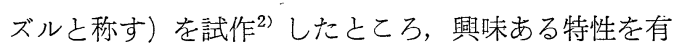
することがわかった. すなわち, 出力特性（出力流 量一出力圧力）に拉いてノズルとその対向面との隙間 が大になると負圧执よび逆流量となる範囲があるこ と, ならびに変換特性（ノズルとその対向面との隙間 一出力流量(圧力)) において高負荷のときの圧力変換 特性のみならず, 低負荷のときの流量変換特性の線形 性がよく， かつそれらの倍率が大きいととである.

このエジェクタ形ノズルは衝突形純流体比例素子の コレクタ部と同じ構造であり，また O. Brychta ${ }^{3)}$ が Small Ejector として発表しているあのと類似してい る.しかし, てれらの研究においては, 特性の理論解 析はなされていない。本報では, エジェクタ形ノズル を厚み計形マイクロメータに用いたとき, 内部の流れ に㧍いて噴流の衝突モデルを設定して噴流衝突部の圧 力上昇が噴流の衝突による運動量変化に基づくものと して, 非圧縮性流れの場合の静特性を理論的に解析 し，実験結果と比較して設計基準を考察している.

\section{2. 実験方法およびその結果}

供試ノズルの構造を Fig. 1 に示す.（a ) は従来の あのを一体化したあのであり，(b)がエジェクタ形 
ズルである、また，Table 1 に供試エジェクタ形ノ ズルの各部寸法を示す。なお普通ノズルについては, $D_{s}=0.10,0.15,0.20 \mathrm{~cm}, D_{n}=0.15,0.20,0.30 \mathrm{~cm}$ のものを作り，組合せて用いた。

出力特性はノズルをその対向面に垂直に移動するテ ーブルを有するトラバース装置に取付け，マイクロメ 一タにてノズルとその対向面との隙間を変え，乙れに 対する出力流量, 出力圧力を測定するととによって求 めた，供給流量および出力流量はロータメータあるい は熱線流速計を用いた流量計にて測定し，また，出力 圧力は出力口に取付けた $0.5 \mathrm{~mm} \phi$ の圧力取出口によ り水柱マノメータに導びき測定した. 出力口には適当 な負荷を与える絞り抵抗を取付け，種々の負荷に対し て出力特性を測定した。なお，供給圧力は，実験中は 減圧調整弁にて一定圧力となるようにした.

Fig. 2 および Fig. 3 亿，それぞれ 1 噴口厚み計 形ノズルおよびェジェクタ形ノズルを用いた空気マイ クロメータの特性の典型的な例を示す，ノズルとその 対向面との陌間 $H$ 一定線が点線にて示されている. （a）は出力流量一出力圧力特性を示し，（b ）はノズル とその対向面との隙間流量一出力圧力特性を示してい る.

出力流量一出力圧力特性曲線に扔いて，隙間一定を 示す点線は Fig. 2 の噴口厚み計形ノズルでは不揃

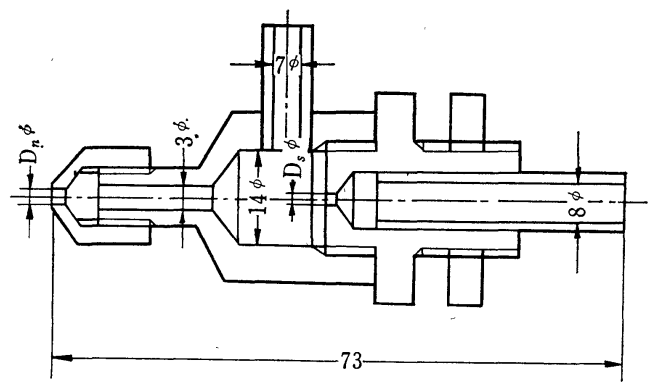

a) Usual type
Table 1

Nomenclature

A: Cross-sectional area, $\mathrm{cm}^{2}$

$C_{e}$ : Ratio of the entrainment flow to the supply flow

$C_{m}$ : Ratio of the momentum

$D$ : Diameter of the cross section, $\mathrm{cm}$

$H$ : Gap between the nozzle and its counter face, $\mathrm{cm}$

$K$ : Constant

$L$ : Length or distance, $\mathrm{cm}$

$L_{s n}$ : Distance from the nozzle to the supply port, $\mathrm{cm}$

$M$ : Momentum, $\mathrm{kg}$

$P$ : Pressure, $\mathrm{kg} / \mathrm{cm}^{2}$

$Q_{e}:$ Entrainment flow rate, $\mathrm{cm}^{3} / \mathrm{s}$

$Q$ : Flow rate, $\mathrm{cm}^{3} / \mathrm{s}$

$R_{e}^{*}$ : Reynolds' number at $P_{0}=0, Q_{0}=0$

$r$ : Radius from the center axis of the jet, $\mathrm{cm}$

$u$ : Flow velocity $\mathrm{cm} / \mathrm{s}$

$\alpha$ : Flow coefficient

$\nu$ : Coefficient of kinematic viscosity, $\mathrm{cm}^{2} / \mathrm{s}$

$\rho$ : Fluid density, $\mathrm{kg} \cdot \mathrm{s}^{2} / \mathrm{cm}^{4}$

$\theta$ : Angle of the nozzle, rad

$\varphi$ : Angle, rad

$\zeta$ : Ratio of the recovery pressure to the energy of return flow

$\lambda_{0}$ : Coefficient which shows the pressure recovery induced by the impinging jet Subscript

$b$ : Low pressure region of the nozzle back pressure chamber

$n$ : Nozzle $\quad 0$ : Output port

$r$ : Return flow $\quad s$ : Supply flow

$11^{\prime}$ : Control surface at section $11^{\prime}$

$22^{\prime}$ : Control surface at section $22^{\prime}$

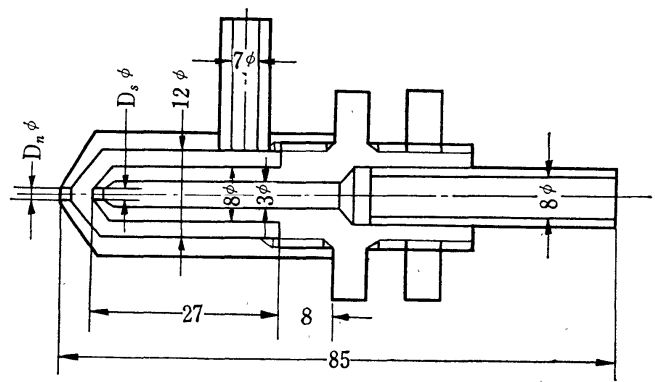

b) Ejector type

Fig. i Nozzle element

Table Dimensions of Ejector type Nozzles

\begin{tabular}{l|lllllll|l}
\hline \hline No. & 110139 & 110170 & 110205 & 150205 & 150300 & 155205 & 155300 & \\
\hline$D_{s}$ & 0.110 & 0.110 & 0.110 & 0.150 & 0.150 & 0.155 & 0.155 \\
$D_{n}$ & 0.139 & 0.170 & 0.205 & 0.205 & 0.300 & 0.205 & 0.300 & \\
$D_{n o}$ & 0.257 & 0.320 & 0.372 & 0.372 & 0.421 & 0.372 & 0.421 & \\
$L_{s n}$ & 0.241 & 0.241 & 0.255 & 0.549 & 0.520 & 0.249 & 0.220 & \\
$L_{n}$ & 0.177 & 0.170 & 0.131 & 0.131 & 0.179 & 0.131 & 0.179 & \\
\hline
\end{tabular}


いであるが, Fig. 3 のエジェクタ形ノズルではほぼ等 しい間隔で同様な形をしている.すなわち，エジェク タ形ノズルでは，変換倍率が隙間の比較的広範囲でほ ぼ一様であり，かつ負荷が変化してもその傾向が保た れている．とくに低負荷における流量変換特性がよい ことは，流量を出力信号として用いたいときに有利で ある。

つぎに，ノズルとその対向面との隙間流量一出力圧 力特性曲線においては，エジェクタ形ノズルの場合， 隙間一定線は隙間が小さいところでは綐軸にほぼ平行 で，かつほぼ等しい間隔である. すなわち，ノズルと その対向面との隙間流量は，負荷のいかんにかかわら ずほぼ一定で，隙間 $H$ にほぼ比例して増加する，し たがって，出力流量が隙間にほぼ比例するようになる ものと思われる.

Fig. 3 に見るように，エジェクタ形ノズルでは負の 出力圧力执よび出力流量となる領域が存在するととが 特長で, それらが零となるときのノズルとその対向面 との隙間は負荷が変化しても変わらないが， ズルの 形状寸法（ノズル直径，供給口直径，ノズルと供給口 間距離など）および供給圧によって異なる.

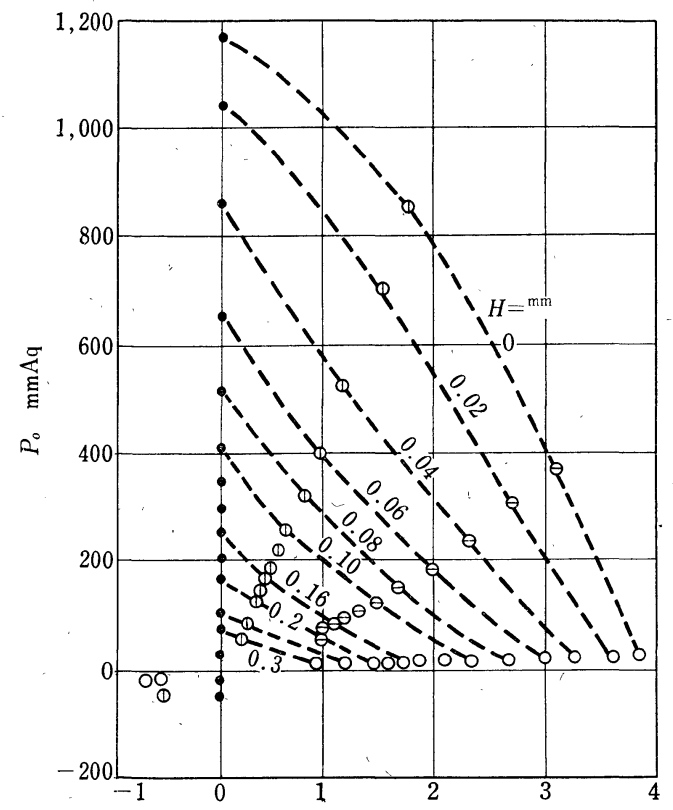

$Q_{o} \quad \mathrm{Nl} / \mathrm{min}$

a) $Q_{o}-P_{o}$ characteristics

\section{3. 理 論 解 析}

\section{1 ノズル室内の流れ}

空気マイクロメータの供給口など，絞り部の上流と 下流との圧力差が $0.2 \mathrm{~kg} / \mathrm{cm}^{2}$ 程度であれば，絞り部 の流れにおいて実用上密度変化を無視してよい. そこ で，本報では非王縮性流の場合について解析する， ノ ズル室内の流れは供給口からの噴流が周囲の流体を巻 込み,ノズルとその対向面に衝突し，一部はノズルと その対向面との隙間から流出し，他は逆流する. 巻込 みのためノズル室内は低圧となり，噴流衝突部の圧力 は運動量変化により上昇する。一方，逆流する流れに よって, 出力口の在る部分の圧力む上昇すると考えら れる.

まず，供給口からの流量は，出力口からの流出量と ノズルとその対向面との隙間からの流出量に等しいか ら, 次式を得る.

$$
Q_{s}=Q_{n}+Q_{0}
$$

つぎに，供給口からの流量は次式で与えられる。

$$
Q_{s}=\alpha_{s} A_{s} \sqrt{2\left(P_{s}-P_{b}\right) / \rho}
$$

ここに流量係数 $\alpha_{s}$ は塚原 $^{4)}$ によれば $2 \alpha_{s}^{2} \fallingdotseq 1$ とす

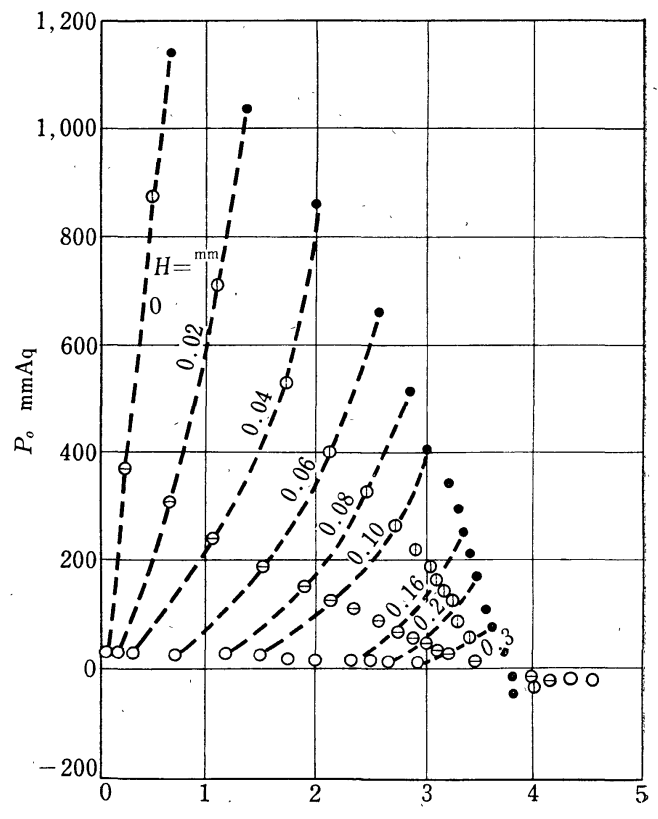

Qo $\quad \mathrm{N} l / \mathrm{min}$

b) $Q_{n}-P_{o}$ characteristics

Fig. 2 Output characteristics of a usual type element when changing the load and the gap between the nozzle and its counter face.

$P_{S}: 0.113 \mathrm{~kg} / \mathrm{cm}^{2} G, D_{S}: 0.092 \mathrm{~cm}, D_{n}: 0.205 \mathrm{~cm}$.

- Blocked load $\left(D_{0}=0 \mathrm{~cm}\right),(1) ; D_{0}=0.07 \mathrm{~cm}, \ominus ; D_{0}=0.14 \mathrm{~cm}, \bigcirc$; Open $\operatorname{Load}\left(D_{0}=0.4 \mathrm{~cm}\right)$ 
る.なお，供給口からの噴流の平均流速は $u_{s}=Q_{s} / A_{s}$

で定義する。

さて，ノズルとその対向面との隙間の流れおよび出 力口の流れは，それぞれ空気マイクロメータの 1 噴口 厚み計形ノズルおよび管孔形ノズルの流れと考えられ る.とれらについて塚原 ${ }^{4)}$ の理論を用いれば，次式を 得る.

$$
\begin{aligned}
& P_{n}=\frac{6 \rho \nu}{\pi H^{3}}\left\{\log \left(\frac{D_{n 0}}{D_{n}}\right)\right\} Q_{n}+\frac{27}{35} \frac{\rho Q_{n}{ }^{2}}{\left(\pi D_{n} H\right)^{2}} \\
& P_{0}=\frac{32 \rho \nu L_{0}}{D_{0}^{2}} \frac{Q_{0}}{\frac{\pi}{4} D_{0}{ }^{2}} \pm \rho\left(\frac{Q_{0}}{\frac{\pi}{4} D_{0}^{2}}\right)^{2}\left(\begin{array}{l}
+: Q_{0} \geq 0 \\
-: Q_{0}<0
\end{array}\right)
\end{aligned}
$$

ととに，式(3)およ゙゙ (4)の右辺の第 1 項および第 2 項は，それぞれ流れの場に拉ける圧力降下の粘性項お よび慣性項を表わす.

上式中の $P_{b}, P_{n}, P_{0}$ は，通常の厚み計形ノズルを使 用した空気マイクロメータではノズル室内の圧力は一 様であるとして扱われるから，静特性はこれらの諸式 により計算される。エジェクタ形ノズルを使用したも のではこの仮定は適用できないと思われるので，以下 に述べるように取扱う。

\section{2 噴流衝突部圧力}

噴流衝突部の圧力は，供給口からの噴流がノズルに 衛突し，一部はノズルとその対向面との陌間から流出 し，他は逆流する際の運動量の変化に基づくものと考 えられる. Fig. 4 に示す衝突噴流の流れのモデルに おける検查面 $12344^{\prime} 3^{\prime} 2^{\prime} 1^{\prime}$ にを考え，うぎの仮定をお $<$.

1）流れは軸対称とし，噴流は偏向しない.

2）供給口から断面 11' に至るまで，噴流は自由噴 流として振舞うが，簡単のため断面 $11^{\prime}$ での流量と運 “動量がそれぞれ等しい一様流速をむつ噴流として扱 う. Fig. 4 亿おける $r_{e}$ はその噴流の半径を示す.

3）断面 $11^{\prime}$ と供給口との距離は，逆流流量が断面 11'での流量とノズルとその対向面との隙間流量との 差に等しくなるところとする。

4) 面 12 加ら逆流する流机は，大きさは断面 $11^{\prime}$ での平均流速㳊しく，方向は面 12 亿垂直である.

5）面 $44^{\prime}$ での流速は， $u_{n}=Q_{n} / A_{n}$ で一様である.

6) 圧力分布は，面 $11^{\prime}$ では $P_{b}$ で一様，面 12 で は $P_{b}$ から $P_{n}$ まで変化すると考えられるが， $\left(P_{b}\right.$ $\left.+P_{n}\right) / 2$ で一様, 面 $2344^{\prime} 3^{\prime} 2^{\prime}$ では $P_{n}$ で一様である.

7) 面 $234,2^{\prime} 3^{\prime} 4^{\prime}$ での粘性摩擦力は, 他の力に比 して小さいとして無視する.

仮定（2）加

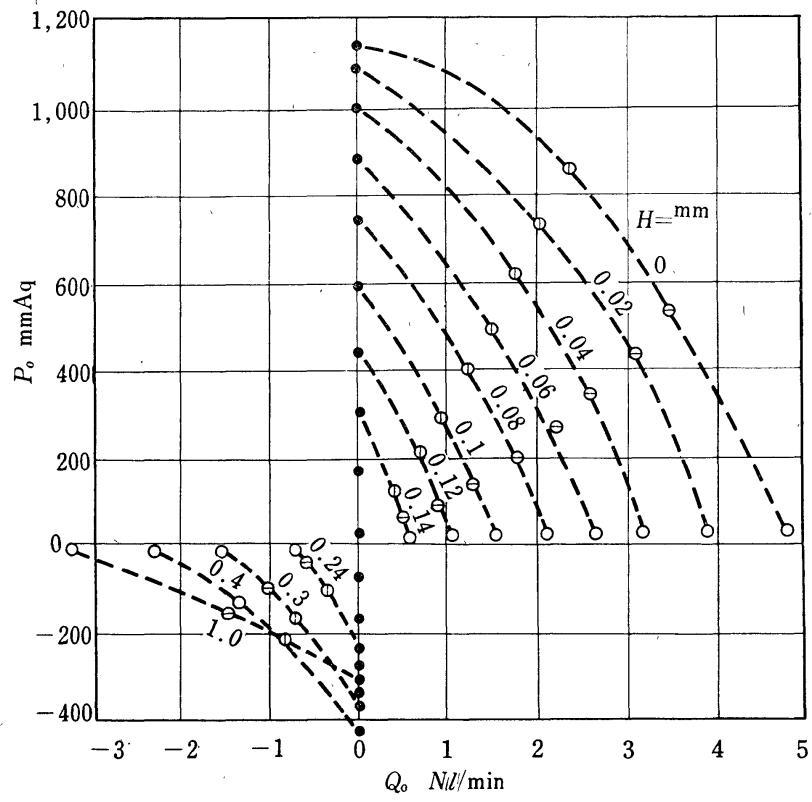

a) $Q_{0}-P_{0}$ characteristics

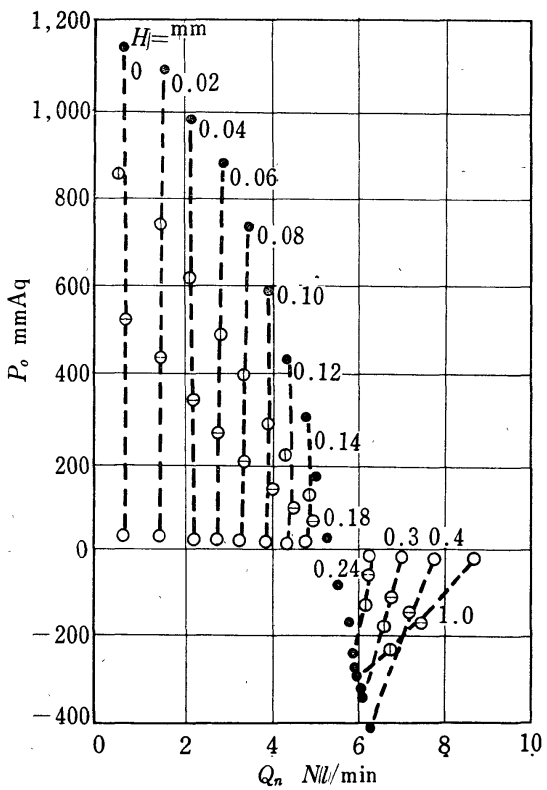

b) $Q_{n}-P_{o}$ characteristics

Fig. 3 Output characteristics of a new type element when changing the load and the gap between the nozzle and its counter face.

$P_{\mathrm{S}}: 0.113 \mathrm{~kg} / \mathrm{cm}^{2} G$, Element No. $110205, D_{S}: 0.110 \mathrm{~cm}, D_{u}: 0.205 \mathrm{~cm}$.

; Blocked load $\left(D_{0}=0 \mathrm{~cm}\right),\left(D ; D_{0}=0.08 \mathrm{~cm}, \Phi ; D_{0}=0.12 \mathrm{~cm}, \bigcirc\right.$; Open load $\left(D_{0}=0.4 \mathrm{~cm}\right)$ 


$$
\begin{aligned}
& Q_{11}=Q_{s}\left(1+C_{e}\right)=4_{11}, \bar{u}_{s}, \\
& M_{11^{\prime}}=\rho Q_{11}, \bar{u}_{s}=C_{m} \rho Q_{s} u_{s}
\end{aligned}
$$

より

$$
\bar{u}_{s}=\left\{C_{m} /\left(\underline{I}+C_{e}\right)\right\} u_{s}
$$

ここに $C_{e}, C_{m}$ は供給口出口に拉ける噴流流速分布を 一様とし，供給口ふらの位置 $L$ での円筒蕡流の流速 分布を多項式近似として次式にて定義する。

$$
\begin{aligned}
& C_{e}=\left\{2 \pi \int_{0}^{r_{c}+r_{e m}} u r d r-Q_{s}\right\} / Q_{s}, \quad Q_{s}=u_{s} A_{s} \\
& C_{m}=\rho\left\{2 \pi \int_{0}^{r_{c}+r_{e m}} u^{2} r d r\right\} / M_{s}, M_{r}=\rho u_{s}^{2} A_{s}
\end{aligned}
$$

ここに流速分布 $u=\left[u_{s} ;\left(r_{c} \leq r\right), u_{s}\left\{1-3.5\left(r-r_{c}\right)^{2} \mid\right.\right.$ $\left.\left.r_{e m}^{2}+2.5\left(r-r_{c}\right)^{3} / r_{e m}^{3}\right\} ;\left(r_{c}+r_{e m} \geq r>r_{c}\right)\right], r_{c}=d_{s} / 2$ $\left\{1-L / L_{0}\right\}, r_{e m}=1.322 D_{s} L / L_{0}, L_{0}=5 D_{s}$.

また，仮定 $(3),(4),(5)$ より，

$$
Q_{r}=Q_{11},-Q_{n}=C_{e} Q_{s}+Q_{0}=A_{r} \bar{u}_{s}
$$

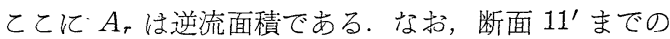
距離が $L_{s n}+L_{n}$ 以上となるときは $L_{11}=L_{s n}+L_{n}$ と した.

さて，運動量の理論より次式を得る.

$$
-P_{b}\left\{A_{22}-A_{r} \sin (\pi-\varphi)\right\}-\frac{P_{b}+P_{n}}{2} A_{r} \sin (\pi-\varphi)
$$

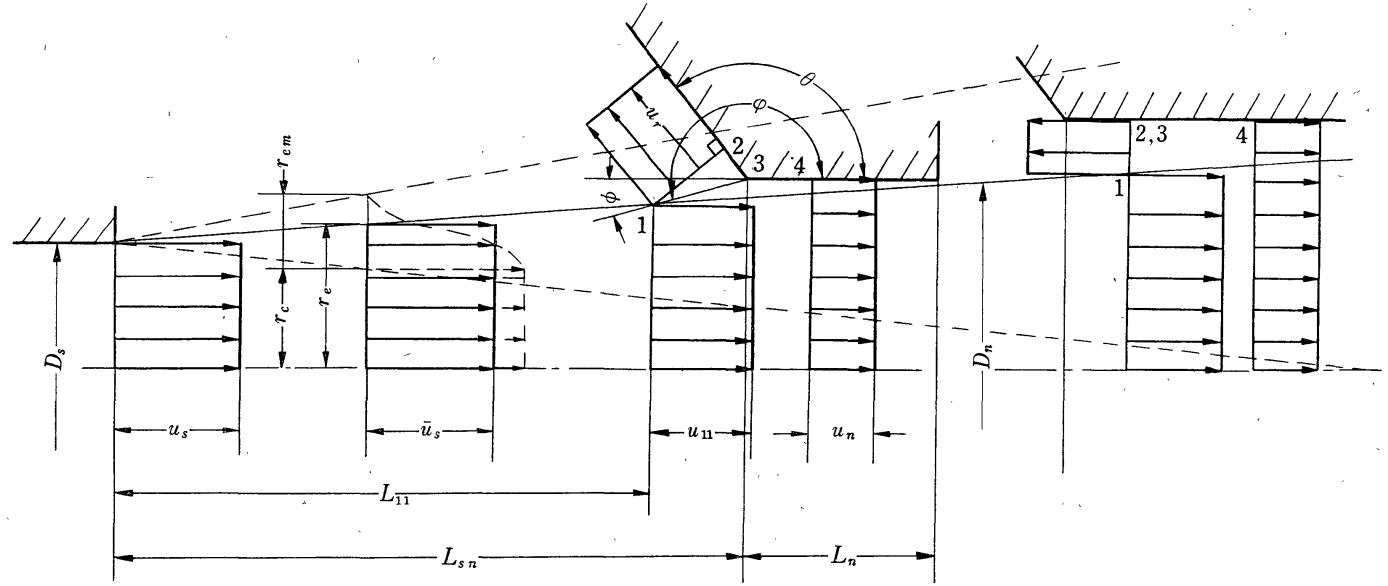

Fig. 4 Flow model

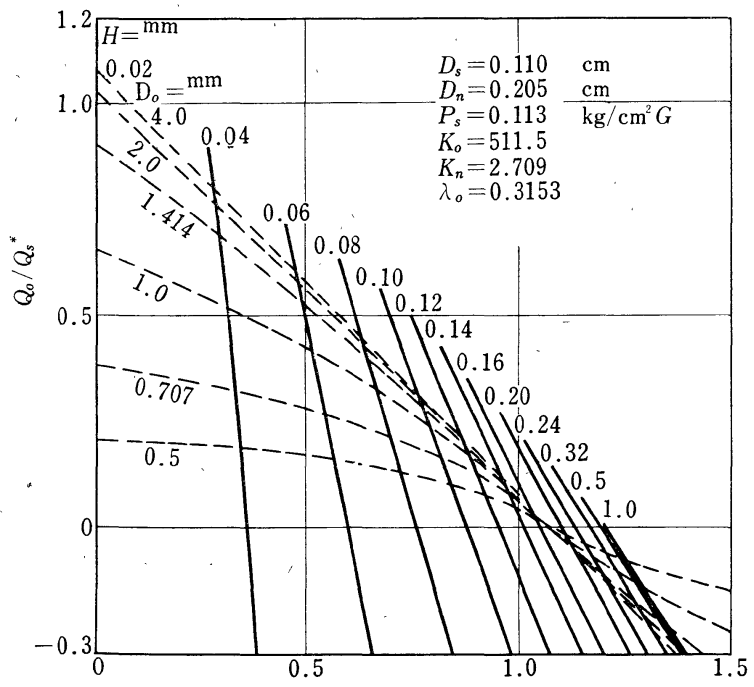

$Q_{n} / Q_{s}^{*}$

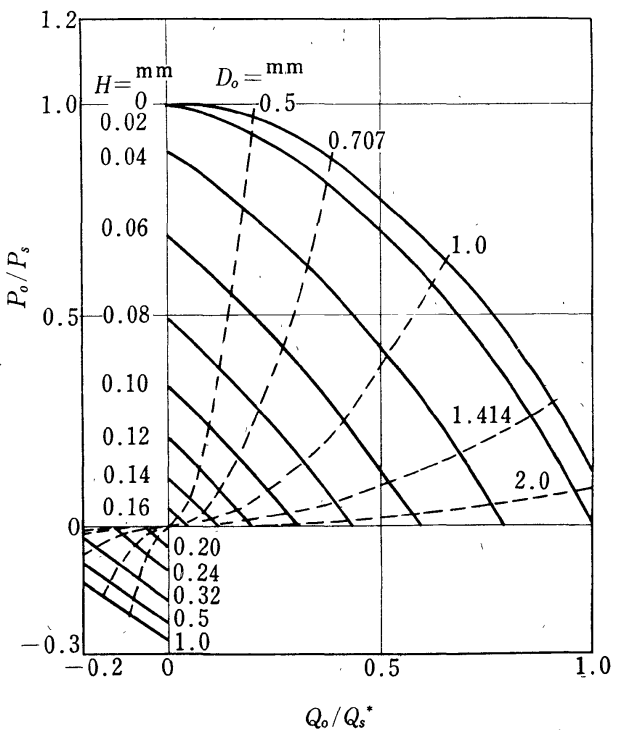

b) Output characteristics

a) Calculated curves of eq (10) $\cdots$ and (11)-.

Fig. 5 Calculated output characteristics of an ejector type nozzle 
$+P_{n} A_{22 \prime}$

$=\rho Q_{11} \bar{u}_{s}-\rho Q_{r} \bar{u}_{s} \sin (\pi-\varphi)-\rho Q_{n} \dot{\bar{u}}_{n}$

ここに

$A_{22^{\prime}}=\pi R_{22^{\prime}}{ }^{2}, \quad R_{22^{\prime}}=D_{n} / 2+\overline{23} / 2 \cos (\pi-\theta), \overline{12}, \overline{23}$ はそれぞれ 12,23 の長さである. また, 角度 $\varphi$ はノズ ルの寸法によって 3 つ場合が考えられる.すなわち，

$$
\begin{aligned}
& \varphi=\left[\theta+\frac{\pi}{2} ;\left(\varphi \leq \frac{\pi}{2}+\theta\right), \arctan \left(\frac{12}{23}\right)+\theta ;\right. \\
& \left.\left(\frac{\pi}{2}+\theta<\varphi \leq \frac{3}{2} \pi\right), \frac{3}{2} \pi ;\left(\frac{3}{2} \pi<\varphi\right)\right] .
\end{aligned}
$$

\section{3 出力圧力}

出力口のある部分の圧力は, 逆流の運動エネルギー

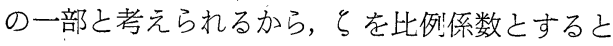

$$
P_{0}-P_{b}=\zeta \rho\left(Q_{r} / A_{r}\right)^{2} / 2
$$

とおける. 式 (5)，(6) を用いると

$$
P_{0}-P_{b}=\zeta \rho\left\{C_{m} /\left(1+C_{e}\right)\right\}^{2} Q_{s}^{2} / 2
$$

\section{4 計算結果}

以上の諸式により出力特性, 変換特性などが計算さ れる. 式(1), (2), (3), (5), (6), (7) より $P_{0}, P_{b}$, $P_{n}, Q_{r}, Q_{s}$ を消去し整理すると，ノズルとその対向面 との隙間の流れ関する次式を得る.

$$
\begin{aligned}
& \left\{\alpha_{0} /(9 h)^{2}+\alpha_{0}{ }^{\prime}\right\} q_{n}{ }^{3}+\left\lceil\beta_{0} /\left(9 \sqrt{K_{n}} h\right)^{3}\right. \\
& \left.\quad+\left\{\beta_{1} /(9 h)^{2}+\beta_{1}\right\} q_{0}\right] q_{n}{ }^{2} \\
& \quad+\left\{\gamma_{0}+\gamma_{1} q_{0} /\left(9 \sqrt{K_{n}} h\right)^{3}+\gamma_{2} q_{0}{ }^{2}\right\rceil q_{n} \\
& \quad+\delta_{1} q_{0}+\delta_{3} q_{0}{ }^{3}=0
\end{aligned}
$$

ここに $q_{n}=Q_{n} / Q_{s}{ }^{*}, q_{0}=Q_{0} / Q_{s}{ }^{*}, h=H D_{n 0} / 2 D_{s}{ }^{2}$, $K_{n} \fallingdotseq 0.0115\left(2 D_{s} / D_{n 0}\right)\left\{R_{e}{ }^{*} / \log \left(D_{n 0} / D_{n}\right)\right\}^{2 / 3}, \quad \alpha_{0}=\beta_{0}$ $=-\gamma_{0}=1, \quad \alpha_{0}{ }^{\prime}=1-\left(\Phi_{1}-1 / a_{n}\right) / B, \quad \beta_{1}=\gamma_{1}=-\delta_{1}=1$ $+\Phi^{\prime} / B, \beta_{1}{ }^{\prime}=3+\left\{\Phi^{\prime}-3 \Phi_{1}+\Phi+1 / a_{n}\right\} / B, \gamma_{2}=3+\left\{2 \Phi^{\prime}\right.$ $\left.-3 \Phi_{1}+2 \Phi\right\} / B, \quad \delta_{3}=1+\left(\Phi^{\prime}-\Phi_{1}+\Phi\right) / B, \Phi=C_{m} \sin (\pi$ $-\varphi) /\left(1+C_{e}\right), \quad \Phi_{1}=C_{m}-C_{m} C_{e} \sin (\pi-\varphi) /\left(1+C_{e}\right), \quad \Phi^{\prime}$ $=\left(1+C_{e}\right) \sin (\pi-\varphi) / 2 C_{m}, B=a_{22}-C_{e} \Phi^{\prime}, a_{n}=A_{n} / A_{s}$, $a_{22}=A_{22} / A_{s}, \quad R_{e}^{*}=\left(D_{s} / \nu\right) V \overline{2 P_{s} / \rho}, \quad Q_{s}^{*}=\alpha_{s} A_{s}$ $\sqrt{2 P_{s} / \rho}$

ノズルとその対向面との隙間 $H$ をパラメータとし て種々の $Q_{0} / Q_{s}$ * について式 (10) を計算した結果を Fig. 5 (a) に実線にて示す. 係数 $\alpha, \beta, \gamma, \delta, K_{n}$ は八 ズルの幾何学的寸法扔よび供給圧力を与えると計算さ れる. 一般的には $Q_{0} / Q_{s}{ }^{*}$ が変化すると $C_{e}, C_{m}$ は変 化するため繰返し計算を必要とするが，てこでは Fig. 3 より明らかなように $P_{0}=0, Q_{0}=0$ のとき負荷 のいかんにかかわらず $Q_{n} / Q_{s}{ }^{*}$ が一致するととから， この点に扔いて $C_{e}, C_{m}$ を決定した.

一方,出力口流机詨しては式(1)，(2)，(4)，(9) より同様に次式を得る.

$$
\begin{aligned}
& \sigma q_{n}^{2}+2 \sigma q_{0} q_{n}-1+\left(1 / K_{0} d_{0}{ }^{4}\right) q_{0} \\
& +\left(\sigma \pm 1 / d_{0}{ }^{4}\right) q_{0}{ }^{2}=0
\end{aligned}
$$

$$
\begin{aligned}
& \text { ここに, } \\
& \quad \sigma=1-\zeta\left\{C_{m} /\left(1+C_{e}\right)\right\}^{2} / 2, K_{0} \fallingdotseq R_{e}{ }^{*} /\left(22.4 L_{0} / D_{s}\right), \\
& \quad d_{0}=D_{0} / D_{s} .
\end{aligned}
$$

出力口負荷絞り徍 $D_{0}$ をパラメータとして計算する

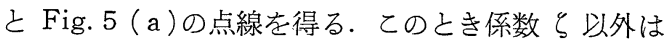
寸法捄よび供給圧を与えると計算される. らは上述と 同樣に， $P_{0}=0, Q_{0} / Q_{s}^{*}=0$ のときの実験結果を用い て次式より決定した

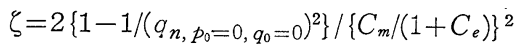

式(10) と (11)の交点 $\left(q_{n}, q_{0}\right)$ が， $H$ および $D_{0}$ を 与えたときの流れの状態を示す.よって,式 (1), (2) および $(9)$ より, 出力圧力が求められる. Fig. 5 (b) は出力特性の例である：素子の形状寸法は, Fig. 3 亿 示したものと同じである。乙れら計算と実験による出 力特性は，比較的よい一致を示している.

\section{4. 考察}

\section{1 エジェクタ形ノズルの特長}

出力特性曲線（Fig. 5 (b ) ) において，ノズルとそ の対向面との隙間一定線がほぼ同様な形であり，隙間 が大になると $P_{0} / P_{s}, Q_{0} / Q_{s}{ }^{*}$ が負之なること，ならび に高負荷にお㳡る出力圧力变換特性のみならず低負荷 にお汀る出力流量変換特性の線形性がより改善される ことが，計算によっても確かめられた。

ノズルとその対向面との隙間の流れに対する式(10) による計算結果を示す Fig. 5（a）の実線が，縦軸に ほぼ平行な曲線群となり，さらに右方に広がってい る. これは，ノズルとその対向面との隙間からの流量 が噴流衝突部の圧力上昇のため増大するととを示す。 したがって，全閉負荷 $\left(D_{0}=0\right)$ のときのノズルとその 対向面との隙間流量について考察することによって, エジェクタ形ノズルの特長を考察することができる。

4.1.1 噴流衙突部の圧力上昇を示すパラメータ $\lambda_{0}$ 今, 式 (1), (6) および (7)を用いると, 全閉負荷 のとき,

$$
\begin{aligned}
& P_{n} / P_{s}-P_{b} / P_{s}=\left(1-\alpha_{0}{ }^{\prime}\right)\left(Q_{n} / Q_{s}{ }^{*}\right)^{2} \\
& \lambda_{0}=1-\alpha_{0}{ }^{\prime}=\frac{C_{m}-\frac{C_{m} C_{e}}{1+C_{e}} \sin (\pi-\varphi)-\frac{1}{a_{n}}}{a_{22}+\frac{\left(1+C_{e}\right) C_{e}}{2 C_{m}} \sin (\pi-\varphi)}
\end{aligned}
$$

を得る．乙の $\lambda_{0}$ は式(12)にみるように，噴流衝突に よる圧力上昇を示すパラメータである. $C_{e}, C_{m}, \varphi, a_{22}$ はノズルの寸法 $A_{n} / A_{s}, L_{s n} / D_{s}, L_{n} / D_{s}$ によって決ま るから $\lambda_{0}$ も同様に計算される.

計算結果を Fig. 6 亿示す.ノズル断面積と供給口 断面積の比 $A_{n} / A_{s}$, ノズルと供給口との距離 $L_{s n} / D_{s}$, 


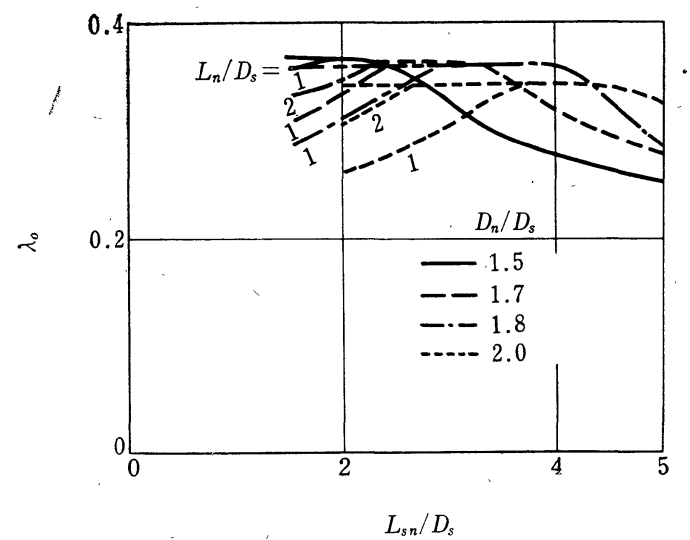

Fig. $6 \quad \lambda_{0}$ versus $L_{S n} / D_{S}$

のある值で $\lambda_{0}$ は最大となり，その最大值は大差なく $\lambda_{0} \fallingdotseq 0.36$ である.ノズル長さ $L_{n} / D$ s が大になると $\lambda_{0}$ は最大值敒等しくなる， $L_{s n} / D s$ が大になる之，衝 突噴流の流速分布および流れのモデルに修正を加えね ばならないと思われるため計算していないが，入0は零 に近づくと思われる。

4.1.2 ノズルとその対向面との隙間流量 式(10)に拉いて， $q_{0}=0, H \rightarrow \infty$ とすると

$$
Q_{n} / Q_{s} *=\sqrt{1 / \alpha_{0}{ }^{\prime}}=\sqrt{1 /\left(1-\lambda_{0}\right)}
$$

となる. Fig. 6 より $0 \leq \lambda_{0}<0.36$ と考えられるから， 上式より隙間が大きいときのノズルとその対向面との 隙間流量は 1 より大となる。計算によれば， $\lambda_{0}$ が大と なると Fig. 6（a）の実線は右方に広がり, 綎軸上平 行するようになる.

\section{2 ノズル形状寸法の効果}

エジェクタ形ノズルを有する空気マイクロメータの 静特性は前節の $\lambda_{0}$ のほかに, $K_{n}, K_{0}, \zeta$゙な゙のパラ メータによって影響される． $K_{n}, K_{0}$ については塚原 によって究明されているが，エジェクタ形ノズル特有 のパラメータではないので，乙こでは論じない．しか し， $K_{n}$ が大になると，出力圧力が最大倍率となる陌 間の值は $H / D_{s} \fallingdotseq 0.6$ で一定であるが, 出力圧力変換 特性は線形性がよくなる。一方，らはエジェクタ形， ズル特有のパラメータであるが，Fig. 6 （a）の点線を 右方に移動させるだけで根本的な要因ではない之思わ れる. 以下に $\lambda_{0}, K_{n}$ に与える形状寸法の効果につい てみる。

\subsection{1 $D_{n} / D_{s}, D_{n 0} / D_{s}$}

ノズルの直径と供給口の直径との比 $D_{n} / D_{s}$, ある いはそれらの面積比 $a_{n}$ の平方根が 1 ～2 とき, 定 数 $\lambda_{0}$ は最大となる.また, ノズル外径とノズルの直 径との比 $D_{n 0} / D_{n}$ が 1 亿近いとき, 定数 $K_{n}$ は大と
なる。

$$
\text { 4.2.2 } L_{s n} / D_{s}, L_{n} / D_{s}
$$

ノズルと供給口間の距離と供給口直径との比 $L_{s n} / D_{s}$ が小さいとき $\lambda_{0}$ は最大值となるが， $D_{n} / D_{s}$ によってそのときの $L_{s n} / D_{s}$ の值は異なる. ノズル の長さと供給口直径との比 $L_{n} / D_{s}$ が小さいとき $\lambda_{0}$ は 小さくなるが，実験においてはその傾向は認学られな い.

\subsection{3 $R_{e}{ }^{*}$}

供給口からの噴流についての標準レイノルズ数 $R_{e}{ }^{*}$ が大になると，定数 $K_{n}$ は大となる．したがって，空 気を動作流体として用いるとき，供給日直径 $D_{s}$ およ び供給圧 $P_{s}$ が大きいほうがよい.

\section{3 実験結果と計算結果との比較}

計算結果と実験結果との一致は，心くつかの点を除 いて比較的よい．をを決定するとき $P_{0}=0, Q_{0}=0$ の ときに一致するようにしたため，その他のノズルとそ の対向面との隙間においてはいくらが差がある．ての 差の理由としては，隙間が小さいところでは供給口か らの噴流の流速は小さく乱流噴流とはいえないとと, ノズル室圧力 $P_{b}=0$ とした標準レイノルズ数 $R_{e}$ * 用いて $K_{n}, K_{0}$ を計算していることなど，一方，隙間 が大きいととろではノズルとその対向面との隙間の流 れが慣性形となり，剝離や縮流などが生じ $K_{n}$ の計算 に用いた流れのモデルが変化しているととが考えられ る.

上述のととは， $P_{0}=0, Q_{0}=0$ となるノズルとその 対向面之の隙間の值についてもいえる. なお，変換特 性の線形性は実験結果のほうが計算結果よりよく，と くにノズル直径と供給口直径の比が大きく, ノズルと 供給口との距離が小さいとき著しい.

\section{4 設計基準}

以上の考察により, エジェクタ形ノズルの設計法が 明らかとなった．エジェクタ形ノズルの特長が著しい のは, ノズル直径と供給口直径との比が $1.3 \sim 2.0$ お よびノズルと供給口との距離と供給口直径との比が 1.0〜4. 0 の範囲である.

必要とする出力信号（圧力あるいは流量）が決まる と, 供給圧, 供給口直径などが決定され, 他の寸法 はつぎのように選ばれる。たとえば $D_{n} / D_{s}=1.8$, $2 \leq L_{s n} / D_{s} \leq 4, L_{n} / D_{s} \geq 2$. な掠，ノズル直径の決定 には要求されるノズルとその対向面との隙間にも関係 し，たとえば回転傾斜円板を対向面とする正弦波信号 発生器のように最大変換倍率となる腙間の值を大きく したい場合，H/Dsう0.6により決定するととが必要 となる。 


\section{5. 結}

\section{言}

空気マイクロメータ用ノズルとして, 供給口, 出力 口およびノズルを一体化して，供給口とノズルを非常 に近接して設置したエジェクタ形ノズルを試作した. 供給圧驾 $0.3 \mathrm{~kg} / \mathrm{cm}^{2}$ 以下の低圧の場合について特性 解析を行ない，そのメカニズムを明らかにし，つぎの 結論を得た。

1）負荷として種々の直径の絞りを用いるとき, 出 力特性においてノズルとその対向面との陌間一定線は 同様な形をしており，隙間が大きくなると出力が負圧 および逆流量となる．高負荷では変換倍率は 1 噴口厚 み計形ノズルに比してほとんど低下しないで，出力圧 力の変換特性の線形性が改善される. 低負荷において 屯, 出力流量変換特性の線形性が優れ変換倍率屯高 ).

2）理論解析の結果，全閉負荷の之きの噴流衝突部 の圧力上昇を示すパラメータ $\lambda_{0}$ がエジェクタ形人ズ ルの特長を表わし， 1 噴口厚み計形ノズルでは $\lambda_{0}=0$ に相当することが明らかとなった。 また，ノズル形状 寸法の静特性に与える効果を調べ，エジェクタ形ノズ ルの設計基準を示した.

3）実験結果之計算結果との一致は比較的よいが, ノズルとその対向面との隙間が大きい範囲にわたると
きは流れの様子が変化するあのと考えられ，パラメー 夕が変化するので，理論には限界がある．また，実験 值のほうが出力特性の線形性がよい.

以上により, 空気信号発生器として，とくに低負荷 に扔いて大流量を必要とする場合に有利であると思わ れる. 残されている問題として, 供給圧が $0.3 \mathrm{~kg} / \mathrm{cm}^{2}$ 以上の中・高圧のときの特性，ノイズおよび動特性な どがあり，てれらは今後の研究課題としたい.

最後に, 本研究に押いて, 終始御指導を賜わった京 都大学花房秀郎教授; 御鞭達を賜わっている福井大学 段野勝教授，ならびに実験に御協力していただいた元 本学大学院生岡林敏隆君および元卒論学生諸君に謝意 を表します。

\section{参 考 文 献}

1）山本 㟶：傾斜円板を利用した空気的信号発生機とその 応用，計测之制御，2-12，988/993 (1963)

2）岡林隆敏：空気式正弦波信号発生装置に関する研究，福 井大学大学院修士論文, (1971-2)

3) Brychta, O.: The "Small Ejector" System, Proc. of Fourth Cranfield Fluidics Conference, E 7, (1972-6)

4) 塚原鶴夫：空気マイクロメータ, (pp. 139 162) 近代 科学社, (昭和 37 年 8 月)

5）鈴木，岡林：空気信号発生器の特性，日本機械学会・精 機学会北信越支部「福井地方講演論文集」, No. 717-3, (1971-12), pp. 113 116 